\title{
Enhanced Wastewater Treatment by Immobilized Enzymes
}

\author{
Jakub Zdarta ${ }^{1}$ (D) Katarzyna Jankowska ${ }^{1}$ - Karolina Bachosz ${ }^{1}$. Oliwia Degórska ${ }^{1} \cdot K^{2}$ arolina Kaźmierczak ${ }^{1}$. \\ Luong N. Nguyen ${ }^{2} \cdot$ Long D. Nghiem $^{2} \cdot$ Teofil Jesionowski $^{1}$
}

Accepted: 31 March 2021 / Published online: 20 April 2021

(C) The Author(s) 2021

\begin{abstract}
Purpose of Review In the presented review, we have summarized recent achievements on the use of immobilized oxidoreductases for biodegradation of hazardous organic pollutants including mainly dyes, pharmaceuticals, phenols, and bisphenols. In order to facilitate process optimization and achievement of high removal rates, effect of various process conditions on biodegradation has been highlighted and discussed.

Recent Findings Current reports clearly show that immobilized oxidoreductases are capable of efficient conversion of organic pollutants, usually reaching over $90 \%$ of removal rate. Further, immobilized enzymes showed great recyclability potential, allowing their reuse in numerous of catalytic cycles.

Summary Collected data clearly indicates immobilized oxidoreductases as an efficient biocatalytic tools for removal of hazardous phenolic compounds, making them a promising option for future water purification. Data shows, however, that both immobilization and biodegradation conditions affect conversion efficiency; therefore, process optimization is required to achieve high removal rates. Nevertheless, we have demonstrated future trends and highlighted several issues that have to be solved in the near-future research, to facilitate large-scale application of the immobilized oxidoreductases in wastewater treatment.
\end{abstract}

Keywords Oxidoreductase $\cdot$ Laccase $\cdot$ Enzyme immobilization · Immobilized oxidoreductase $\cdot$ Emerging contaminants · Environmental protection

\section{Introduction}

Due to the increasing environmental pollution, which is majorly caused by anthropogenic activities (man-made processes), the people are now more concerned around the globe. The increasing number of various types of organic pollutants, including phenols, pharmaceuticals, pesticides, dyes, estrogens, and personal care products, is increasingly being detected in our water systems and wastewater [1-3]. Their presence in unknown and uncontrolled dosages undesirably compromises the quality of water and shows a

This article is part of the Topical Collection on Water Pollution

Jakub Zdarta

jakub.zdarta@put.poznan.pl

1 Institute of Chemical Technology and Engineering, Faculty of Chemical Technology, Poznan University of Technology, Berdychowo 4, PL-60965 Poznan, Poland

2 Centre for Technology in Water and Wastewater, University of Technology Sydney, Ultimo, New South Wales 2007, Australia serious risk to human beings and aquatic organisms $[4,5]$. Most of the abovementioned substances are also known as emerging contaminants (ECs) and are classified by the World Health Organization as group 1 of carcinogens due to their potentially mutagenic and cancerogenic character [6]. This issue is inevitably increased because of the lack of efficient technologies for the proper disposal, management, and recycling of waste. Further, unfortunately, most of these substances are resistant to classical treatment approaches and are not being efficiently removed during the present-day wastewater treatment plants [7]. Most of the recently applied methods of EC removal suffer also due to low efficiency and generation of many by-products and wastes. For example, in ozonation and photocatalysis, which are one of the most often methods used in wastewater treatment plant, toxic solvents are used and the toxic products after degradation process are present. Moreover, these methods need high energy input, which causes that they are relatively expensive, due to production of ozone and use of high-energy consumable UV lamps [8,9]. In case of other methods, such as filtration, coagulation, or chemical flocculation, they generate secondary disposal problem [10]. 
Therefore, it has become meaningful to develop and optimize alternative technology that is sustainable, essentially smart, greener, and environmentally competent. In this context, biological methods of pollutant removal concerning use of microorganisms and/or enzymes seem to be of particular interest [11]. Particularly, enzymes such as laccases and tyrosinases, manganese, horseradish, lignin, and phenol peroxidases hold a promising role to mitigate any kinds of contamination including a wide range of phenolic compounds in a specific, easy-to-monitor, and highly controllable manner [12]. Enzyme-based processes offer also many other advantages such as low energy input, low toxicity, ability to operate under mild conditions, reduced amount of sludge, and by-product generation [13, 14]. Nevertheless, use of free enzymes for such purposes at an industrial scale has several difficulties including mainly low stability of the biocatalysts at harsh process conditions as well as extremely limited reusability of the free enzymes. In order to improve enzymes catalytic properties and stability and produce highly efficient and robust biocatalytic systems, enzyme immobilization might be applied [15, 16]. Enzyme immobilization results in formation of heterogeneous catalysts characterized by improved stability at harsh process conditions. Furthermore, storage stability and operationability of the enzymes increase significantly upon immobilization. Finally, the greatest advantage of the immobilized enzyme is improvement of enzyme recycling and reusability that increases the biocatalytic productivity of the biocatalysts and reduces costs of the entire process [17]. Although immobilized oxidoreductases recently have been reported to be efficient for removal of water pollutants, special attention should be paid to the proper selection of the support material and immobilization approach in order to reduce negative effect of the immobilization on catalytic action of the enzymes [18].

In this review article, we summarized recent progress in the use of biocatalytic systems based on immobilized laccase, tyrosinase, and peroxides for removal and/or conversion of various hazardous contaminants including mainly phenol and its derivatives, pharmaceuticals, estrogens, dyes, and other phenolic compounds from water and wastewater. We highlighted current research achievements in this field with particular emphasis of the effect of various process parameters on removal efficiency of pollutants at a minimal environmental impact and stability of the immobilized enzymes. In addition, effects of selected support material and immobilization approach on catalytic properties of the oxidoreductase and process operationability have been discussed to facilitate the largescale application of the biocatalytic systems for water treatment.

\section{Biological Treatment of Water and Wastewater}

As mentioned above, traditional physical and chemical methods of environmental pollutant removal are widely used including adsorption, sedimentation, ozonation, or advanced chemical oxidation $[19,20]$. Unfortunately, due to their disadvantages such as production of hazardous by-products, use of toxic solvents, requirement for sophisticated equipment, high overall costs of the process, or even incompatibility for complete removal of phenolic compounds, more and more attention is being paid to the remediation of these compounds by biological methods. It is caused by the fact that they can effectively remove phenolic contaminants in accordance with the rules of green chemistry, under mild process conditions, without the use of additional hazardous chemicals, and generation of toxic by-products and sludge might be avoided [21, 22]. The biological methods of pollutant removal are used in both laboratory- and large-scale applications and, in general, can be divided into two major ways: (i) treatment by microorganisms and (ii) treatment by enzymes in the free and immobilized form [23].

The use of whole microorganisms in removal process of pollutants from wastewaters is widely described in the literature. The most popular bacteria used for these processes are Pseudomonas and Streptomyces, whereas in case of fungi, white-rot fungal species, such as Trametes versicolor and Pleurotus ostreatus, are mainly used [24]. It should be highlighted that due to the great variety of different microbial species, the process can occur in aerobic, anaerobic, and mixed aerobic-anaerobic conditions. Anaerobic and aerobic treatments differ by the presence of oxygen in the process. In case of anaerobic treatment, there is no oxygen that leads to the production of highly toxic aromatic amines [25]. By contrast, aerobic conversion results in less toxic products; however, a longer process time is required. These bacterial microorganisms create and activate sludge that is capable of removal of pollutants not only by their conversion but also by adsorption of the toxic pollutants. However, also microbiological methods are effective in the removal of the most of pollutants presented in wastewater, but they are ineffective in the removal of phenolic compounds such as pharmaceuticals, dyes, or phenols. This is mainly due to the resistance of these compounds to microbiological treatment, insufficient amount of the enzymes in microbial cells, as well as diffusional limitations in transport of substrates [26].

Enzymes, mainly from oxidoreductase group, including laccases, peroxidases, and tyrosinases, arouse as a promising alternative for biological treatment of water and wastewater. These biomolecules are capable of catalyzing oxidation reactions of a large number of organic compounds, mainly phenolic and non-phenolic aromatic molecules [27-30]. Catalytic properties of such enzymes made them attractive for transformation of various ECs such as pharmaceuticals, estrogens, dyes, pesticides, as well phenol and its derivatives [18, 31]. Due to catalytic conversion of hazardous molecules, it is possible to obtain products, characterized by lower toxicity, compared to substrates. Besides achievement of high removal rate, 
enzymatic conversion leads to production of less toxic products, which might be easily separated from post-reaction mixture [32]. However, free enzymes suffer due to their low stability and extremely limited reusability. In these terms, immobilized oxidoreductases were proposed as versatile biocatalytic tools for removal of pollutants [33, 34]. Immobilization provides improvement of stability of the biomolecules and facilitates their reuse over repeated bioremediation cycles. Further, use of immobilized enzymes gives an opportunity to develop novel bioremoval approaches including, among others, simultaneous adsorption and biodegradation or use of enzymatic membrane bioreactors [16]. However, to obtain highly active biocatalytic systems, it is essential to properly select support material for immobilized enzyme. In general, organic, inorganic, and hybrid/composite materials are commonly used for oxidoreductase immobilization. These materials should be characterized by high stability and mechanical resistance and biocompatibility with enzymes and should have high affinity towards immobilized biomolecules. Further, the presence of numerous chemical moieties is also highly desired in order to facilitate strong enzyme binding. Although various materials can be used, of particular interest are hybrid and composite materials due to their tailor-made properties that are designed to ensure high enzyme activity and stability [35]. It should be highlighted that the use of free and immobilized oxidoreductases usually results in over $90 \%$ of pollutant removal [12, 36-40]. In this review, we have summarized recent findings on biodegradation of hazardous dyes, pharmaceuticals, phenols, and bisphenols by immobilized laccase, tyrosinase, and peroxidases, as we strongly believe that application of immobilized systems is the most promising direction for sustainable and efficient large-scale conversion of persistent organic pollutants.

\section{Wastewater Treatment by Immobilized Enzymes}

\section{Removal of Dyes}

Nowadays, one of the most toxic groups of the environmental pollutants is dyes. This fact is caused by increasing consumption of textiles and everyday objects, which are colored by mainly anthraquinone, azo, and triarylmethane dyes [41]. These compounds get easily through wastewater from households as laundry's wastes; however, the biggest amount of dyes is released directly from textile industry as wastes after dying processes [42]. Improper wastewater treatment causes dyes to migrate into various water areas, such as seas, rivers, or even groundwater. Dyes can easily accumulate throughout the food chain, and due to their toxic and carcinogenic properties, they can affect physiological processes of polluted ecosystem [43]. Moreover, dyes widely used in textile industry, such as Direct Blue 15 and Disperse Blue 291, may cause mutation and denaturation of DNA in human cells [44-46]. Therefore, it is important to produce immobilized enzymes for effective removal of dyes from wastewaters and for reduction of toxicity of solution after treatment. Properly designed and produced biocatalytic systems based on oxidoreductases may be effective tools for conversion of this type of pollutants (Table 1).

The enzyme considered as an effective tool for dye decolorization from water solutions is laccase. There are recent reports concerning application of this oxidoreductase in the immobilized form for decolorization of dyes from real textile wastewaters. Yavaşer and Karagözler [47] used laccase from Trametes versicolor immobilized onto glycidyl methacrylate (GMA)-functionalized polyacrylamide-alginate cryogel (PAG) as a tool for decolorization of dyes from real textile wastewater containing different dyes, salts, and other chemicals using in the dying process. Enzyme covalently bonded through the epoxy groups of the glycidyl methacrylate-decolorized dyes from real textile effluents with over $55 \%$ efficiency at $\mathrm{pH} 5.0$ and $25^{\circ} \mathrm{C}$. In a work by Sondhi et al. [48], laccase was entrapped into $\mathrm{Cu}$-alginate beads and applied for decolorization of dyes from textile dye effluent in continuously packed bed bioreactor. The relatively high value of decolorization efficiency, which exceeded $65 \%$, was probably caused by the addition of 2,2'-azino-bis [3ethylbenzthiazoline-6-sulphonic acid] (ABTS) as a mediator. Moreover, the produced biosystem was characterized by almost $100 \%$ retention of its relative activity after 4 catalytic cycles and after 15 days of storage. Authors explained this by the presence of copper ions in the structure of support that improve the catalytic activity of multicopper oxidase. In other work, bacterial laccase from Escherichia coli immobilized onto polyhydroxybutyrate beads (PHBs) was used for the decolorization process of Direct Red 105, Direct Yellow 106, and Direct Black 112 from real solution containing various inhibitors such as salts, tensoactives, and dispersants. The decolorization efficiency was $60 \%$. Moreover, it was proven that the presence of other chemicals in wastewaters did not significantly affect the decolorization process [49]. As was shown by Khazravi et al. [50], application of laccase immobilized onto oxidized, activated carbon could not only decolorized dye solution but also allowed the use of support material as a self-cleaning adsorbent. It was shown that decolorization efficiency of Reactive Blue 19 was around $80 \%$, but the $40 \%$ degradation efficiency was obtained by catalytic conversion of selected dye, and the rest was reached by adsorption of dye molecules onto support.

Besides laccases, the special attention should be paid on other oxidoreductases, such as peroxidases. Jankowska et al. [51] examined the possible application of immobilized peroxidase from horseradish in the removal of Reactive Black 5 and 
Table 1 Selected examples of dye removal by immobilized oxidoreductases

\begin{tabular}{|c|c|c|c|c|c|}
\hline Enzymes & Support & $\begin{array}{l}\text { Immobilization } \\
\text { method }\end{array}$ & Target compound & $\begin{array}{l}\text { Reusability, storage } \\
\text { stability }\end{array}$ & Ref. \\
\hline $\begin{array}{l}\text { Laccase from Trametes } \\
\text { versicolor }\end{array}$ & $\begin{array}{l}\text { Glycidyl methacrylate } \\
\text { (GMA)-functionalized } \\
\text { polyacrylamide-alginate } \\
\text { cryogel (PAG) }\end{array}$ & Covalent binding & Real textile wastewater & $50 \%$ after 5 cycles & [47] \\
\hline Laccase Bacillus sp. MSK-01 & $\mathrm{Cu}$-alginate bead & Entrapment & Textile dye effluent & $\begin{array}{l}100 \% \text { after } 4 \text { cycles, } \\
100 \% \text { after } 15 \text { days of } \\
\text { storage }\end{array}$ & [48] \\
\hline $\begin{array}{l}\text { Laccase from Escherichia } \\
\quad \text { coli }\end{array}$ & $\begin{array}{l}\text { Poly-hydroxybutyrate (PHB) } \\
\text { beads }\end{array}$ & Covalent binding & $\begin{array}{l}\text { Direct Red 105, Direct } \\
\text { Yellow 106, Direct } \\
\text { Black } 112\end{array}$ & n.a. & [49] \\
\hline $\begin{array}{l}\text { Commercially available } \\
\text { laccase }\end{array}$ & Oxidized activated carbon & Covalent binding & Reactive Blue 19 & n.a. & [50] \\
\hline Horseradish peroxidase & Polyamide 6 (PA6) & $\begin{array}{l}\text { Adsorption/covalent } \\
\text { binding }\end{array}$ & $\begin{array}{l}\text { Reactive Black } 5 \text { (RB5), } \\
\text { Malachite Green (MG) }\end{array}$ & $\begin{array}{l}70 \% \text { after } 20 \text { cycles, } 74 \% \\
\text { after } 30 \text { days }\end{array}$ & [51] \\
\hline $\begin{array}{l}\text { Manganese peroxidase from } \\
\text { Phanerochaete } \\
\text { chrysosporium }\end{array}$ & Chitosan beads & Cross-linking & Real textile effluent & $60 \%$ after 10 cycles & [52] \\
\hline $\begin{array}{l}\text { Manganese peroxidase from } \\
\text { Anthracophyllum discolor }\end{array}$ & $\mathrm{Fe}_{3} \mathrm{O}_{4} /$ chitosan & Covalent binding & $\begin{array}{l}\text { Methylene Blue, Reactive } \\
\text { Orange } 16\end{array}$ & $\begin{array}{l}86 \% \text { after } 5 \text { cycles, } 60 \% \\
\text { after } 14 \text { days }\end{array}$ & [53] \\
\hline
\end{tabular}

n.a. not available

Malachite Green from water solutions imitating seawater. Two approaches of enzyme immobilization, including adsorption and covalent binding using glutaraldehyde as a linker, onto electrospun polyamide- 6 fibers, were compared in the decolorization process of model solutions. It was shown that retention of over $70 \%$ of relative activity after 20 catalytic cycles was noticed for horseradish peroxidase (HRP) immobilized using covalent binding. After the same number of catalytic cycles, HRP adsorbed onto electrospun fibers possessed $63 \%$ of its initial catalytic activity. However, the highest decolorization efficiencies of dyes were obtained after application of adsorbed enzyme. It is related to the presence of salts in imitating seawater solutions, which negatively affect the covalent linkage between support and biomolecule that, in consequence, decreases the activity of HRP covalently bonded. As presented by Bilal et al. [52], peroxidases may be not only a versatile tool for decolorization of dye solution, but also they can decrease dye toxicity after enzymatic treatment. Manganese peroxidase (MnP) immobilized onto chitosan beads by cross-linking with glutaraldehyde facilitates decolorization of dyes in textile effluents even up to $97 \%$. In case of cytotoxicity and mutagenicity studies, they were reduced significantly, even up to around $70 \%$. Besides the type of immobilized enzymes, the dye degradation process plays an important role in the support material. Siddeeg et al. [53] showed a role of applied support in enzyme immobilization and application in removal of dyes. They prepared nanocomposite from chitosan and $\mathrm{Fe}_{3} \mathrm{O}_{4}$ nanoparticles covered by $N$-(3-dimethylaminopropyl)- $N^{\prime}$-ethylcarbodiimide hydrochloride, characterized by a high surface area, suitable for manganese peroxidase attachment. The presence of magnetic particles in the produced support allowed to separate biosystem from dye solution after treatment by using simple external magnetic field. What is more, the fabricated support with immobilized manganese peroxidase was used for decolorization of Reactive Orange 15 and Methylene Blue with $96 \%$ and $98 \%$ efficiency levels, respectively. As presented, the efficiencies of enzymatic decolorization of dyes from textile effluents depend on enzyme origin, type of support, the presence of other compounds in solutions such as salt ions and surfactants, and the process conditions. Although it is necessary to still look for novel systems with immobilized enzymes for dye removal, recent findings show satisfactory results of dye treatment by immobilized oxidoreductases.

\section{Removal of Pharmaceuticals and Estrogens}

Taking into account the dynamic development of pharmaceutical market, veterinary and human medicines, and rising amount of drugs, antibiotics, or hormones making a problem of water pollution by pharmaceutical residues is significant. Medicines are not fully metabolized by living organisms and partially end up in wastewater and then in a sewage treatment plant where they are to be disposed of. Unfortunately, the currently used methods of pollution treatment do not fully degrade trace amounts of medicinal substances or hormones, so new methods of removing them are sought, which may be the use of immobilized enzymes [54]. Pharmaceutical active 
compounds can be successfully removed from wastewater by immobilized oxidoreductases (Table 2).

Laccase from Trametes versicolor immobilized by covalent binding onto polyacrylonitrile-biochar membrane was used for removal of three types of pharmaceuticals: antibiotic, antidepressant, and anti-inflammatory. Support was modified with $10 \% \mathrm{v} / \mathrm{v} \mathrm{HNO}_{3} / \mathrm{H}_{2} \mathrm{SO}_{4}(50: 50 \mathrm{v} / \mathrm{v})$, where $-\mathrm{COOH}$ groups were formed onto polyacrylonitrile (PAN) and biochar, and after that, it was treated with $10 \%(\mathrm{v} / \mathrm{v})$ ethylenediamine. Chlortetracycline, carbamazepine, and diclofenac were at an environmentally relevant concentration in batch mode and were removed in $63 \%, 48 \%$, and $72 \%$, respectively. Immobilized enzyme showed $94 \%$ of its initial activity after 30 days of storage, while free enzyme kept only $32 \%$ of its initial activity. Further, biocatalyst retained around $20 \%$ of its initial activity after 10 cycles and had better thermal, $\mathrm{pH}$, and storage stability than free laccase [55]. In a different study, it was proved that biocatalyst graphene oxide-laccase can be used for successful ibuprofen and diclofenac degradation. In addition, vanillin was used as a mediator to improve the reaction rate allowing $100 \%$ removal. The final products were found to be small-mass and biodegradable compounds, such as 4-isobutylacetophenone, $N$-(2,6-dichlorophenyl)indolin-2-one, 2-(2,6-dichlorophenylamino) benzaldehyde, and 2,6-dichloroaniline [64]. Naghdi et al. [56] obtained a biocatalyst, which consisted of acid-treated (by $\mathrm{H}_{2} \mathrm{SO}_{4} / \mathrm{HNO}_{3}$ ) nanobiochar as a support and immobilized laccase (from Trametes versicolor) by adsorption method. After 5 days of storage test, activity of immobilized enzyme was much higher than that of free enzyme. Its activity dropped to $42 \%$, while for immobilized one, it dropped only to $69 \%$. Biocatalyst was used for degradation of carbamazepine and showed $83 \%$ and $86 \%$ removal of the pharmaceutical from spiked water and secondary effluent, respectively. In another study, removal of tetracycline by bentonite-derived mesoporous materials with laccase immobilized by physical adsorption was investigated. In this case, immobilization improved enzymes' stability in a wide range of temperatures and showed more potential than free enzyme. Removal efficiency of tetracycline by biocatalyst in the presence of 1-hydroxybenzotriazole (HBT) was over 60\% after $3 \mathrm{~h}$ of degradation process. After 4 repeated cycles, biocatalyst retained more than $50 \%$ of its initial activity, which may be due to the poor binding of the enzyme to the carrier and biocatalyst elution between cycles [57]. 'Garcia-Delgado et al. [58] immobilized laccase into support (biochar and stevensite) by covalent binding. Support was aminopropylated with $2 \%(\mathrm{v} / \mathrm{v})$ solution of 3 aminopropyltriethoxysilane (APTES) in acetone. The investigated removal of estrogenic activity of tetracycline obtained very low or no residual activity after catalytic removal. They proved that the use of immobilized laccase coupled to ABTS or syringaldehyde enabled the high removal rates of three tetracyclines at $100 \%$ and $69-100 \%$, respectively. For instance, biochar-immobilized laccases coupled to ABTS were able to remove the activity completely from the solutions of

Table 2 Selected examples of pharmaceuticals and estrogens removal by immobilized oxidoreductases

\begin{tabular}{|c|c|c|c|c|c|}
\hline Enzymes & Support & $\begin{array}{l}\text { Immobilization } \\
\text { method }\end{array}$ & Target compound & $\begin{array}{l}\text { Reusability, storage } \\
\text { stability }\end{array}$ & Ref. \\
\hline Laccase from Trametes versicolor & Polyacrylonitrile-biochar membrane & $\begin{array}{l}\text { Covalent } \\
\text { binding }\end{array}$ & $\begin{array}{l}\text { Chlortetracycline, } \\
\text { carbamazepine, and } \\
\text { diclofenac }\end{array}$ & $\begin{array}{l}94 \% \text { after } 30 \text { days } \\
\text { in } 4{ }^{\circ} \mathrm{C}\end{array}$ & [55] \\
\hline Laccase from Trametes versicolor & Biochar treated with acid & Adsorption & Carbamazepine & $\begin{array}{l}15 \% \text { of after } 30 \\
\text { days }\end{array}$ & {$[56]$} \\
\hline Laccase from Trametes versicolor & Bentonite-derived mesoporous materials & Adsorption & Tetracycline & $50 \%$ after 4 cycles & {$[57]$} \\
\hline Laccase from Trametes versicolor & Biochar and stevensite & $\begin{array}{l}\text { Covalent } \\
\text { binding }\end{array}$ & Tetracycline & $\begin{array}{l}73 \% \text { after } 3 \text { months } \\
\text { at } 4{ }^{\circ} \mathrm{C}\end{array}$ & [58] \\
\hline Laccase from Trametes versicolor & Rigid tripolyphosphate-treated chitosan & $\begin{array}{l}\text { Covalent } \\
\text { binding }\end{array}$ & Tetracycline & n.a. & [59] \\
\hline Horseradish peroxidase & $\begin{array}{l}\text { Poly (vinyl alcohol)/poly (acrylic } \\
\text { acid)/SiO } \mathrm{S}_{2} \text { electrospinning nanofibrous } \\
\text { membrane }\end{array}$ & $\begin{array}{l}\text { Covalent } \\
\text { binding }\end{array}$ & Paracetamol & $60 \%$ after 30 days & {$[60]$} \\
\hline $\begin{array}{l}\text { Laccase from Trametes versicolor } \\
\text { and Myceliophthora } \\
\text { thermophila }\end{array}$ & Polymeric beads and ceramic membranes & Adsorption & $\begin{array}{r}\text { Estrone, } 17 \beta \text {-estradiol, } \\
17 \alpha \text {-ethinylestradiol }\end{array}$ & n.a. & [61] \\
\hline $\begin{array}{l}\text { Laccase from Pycnoporus } \\
\text { sanguineus }\end{array}$ & $\mathrm{Ca}$ and $\mathrm{Cu}$-alginate-chitosan composite & Entrapment & $17 \alpha$-Ethinylestradiol & $70 \%$ after 3 cycles & [62] \\
\hline Laccase from Pleurotus ostreatus & Luffa cylindrica fibers & Adsorption & $17 \alpha$-Ethinylestradiol & $\begin{array}{l}30 \% \text { after } 10 \\
\text { cycles, } 50 \% \text { after } \\
30 \text { days }\end{array}$ & [63] \\
\hline
\end{tabular}

n.a. not available 
tetracyclines and sulfathiazole. Additionally, catalyst in the presence of syringaldehyde removed $100 \%$ of chlortetracycline. In another study, rigid tripolyphosphate-treated chitosan was used as laccase support for tetracycline removal. Support surface was at first treated with tripolyphosphate and, after that, was activated with glutaraldehyde. Effects of mediators were investigated, including ABTS and lignophenolic mediators like violuric, syringic, and ferulic acids; 1 hydroxybenzotriazole; and vanillin. ABTS was determined as the most suitable electron mediator for laccase activation. With the addition of this compound, the bacterial cell growth recovery was at the level of over $98 \%$, which suggested successful inactivation of the antibiotic. When enzyme or mediators were not present in the reaction, the cell growth was fully inhibited, suggesting the presence of functionally active antibiotic. Biocatalyst with other mediators used individually showed no tetracycline activity inhibition. Immobilized enzyme showed also better thermal stability and retained $80 \%$ activity after $7 \mathrm{~h}$ of incubation at $60^{\circ} \mathrm{C}$, whereas free enzyme showed only $50 \%$ of its initial activity [59]. Poly (vinyl alcohol)/poly (acrylic acid) $/ \mathrm{SiO}_{2}$ electrospinning nanofibrous membrane with fiber diameters of 200 to $300 \mathrm{~nm}$ was used as horseradish peroxidase support for paracetamol removal. The membrane used in this process was prepared by thermal cross-linking. Such produced material was activated by $1,1^{\prime}$ carbonyldiimidazole and used for immobilization of horseradish peroxidase. Immobilized HRP retained almost $80 \%$ of its initial activity. The obtained biocatalyst showed also great storage stability (over 60\% after 30 days) and reusability; after 4 cycles, the paracetamol removal rate was around $80 \%$, and after 7 cycles, removal was still at about $40 \%$. Removal rates for immobilized and free horseradish peroxidases are quite similar and equal to $83.5 \%$ and $84.4 \%$, respectively, but the reusability of the immobilized enzyme definitely outweighs its advantage [60].

Big environmental problem is also tray amounts of hormones remaining in the wastewaters. Removal of these compounds is crucial in order to limit their entry into natural waters. Hormones, such as estrogens, can be successfully degraded even by small amounts of enzymes. Becker et al. [61] tested laccase from Trametes versicolor and Myceliophthora thermophila immobilized using two supports, porous polymeric IB-EC1 beads with polyacrylic and carboxylic acids and ester as a functional groups and ceramic membranes, for removal of estrogens in spiked water samples and in real wastewater. After treatment, the estrogenicity was removed in $91 \%$ after $24 \mathrm{~h}$ by immobilized laccase, where for free enzyme, no activity was removed. It was also shown that for the membrane bioreactor constructed with ceramic membrane, over $95 \%$ of estriol was removed, while for the packed bed bioreactor, around $80 \%$. Garcia et al. [62] immobilized laccase on $\mathrm{Ca}$ and $\mathrm{Cu}$-alginate-chitosan composite by entrapment method for $17 \alpha$-ethinylestradiol removal. Upon immobilization, catalytic degradation of the hormone was more efficient in a wider range of $\mathrm{pH}$ and temperature, as compared to the process catalyzed by free enzyme. The highest percentage of removal equal to $80.5 \%$ was reached, or $\mathrm{Cu}$-beads-laccase was obtained after $24 \mathrm{~h}$ at $\mathrm{pH} 5$, with a temperature of $28{ }^{\circ} \mathrm{C}$. Further, after 3 cycles of $17 \alpha$ ethinylestradiol $\left(\mathrm{EE}_{2}\right)$ removal, its yield reached more than $70 \% .17 \alpha$-Ethinylestradiol removal can also be attained by laccase immobilized onto Luffa cylindrica fibers. The best conditions for high laccase activity were at a temperature between 30 and $50{ }^{\circ} \mathrm{C}$ and at $\mathrm{pH}$ ranging from 3.6 to 4.6. $\mathrm{EE}_{2}$ removal efficiencies for free and immobilized enzymes were similar, but those for immobilized enzymes are more financially advantageous due to reuse possibility. Taking into account the type of immobilized laccase, the reusability potential is equal to more than $50 \%$ after 7 cycles [63].

\section{Removal of Phenols}

Phenols are characterized by poor solubility in water and relatively good solubility in fats and, as a consequence, can accumulate in plant and animal organisms. In addition, they are dangerous to the health and life of living organisms because they are highly toxic, corrosive, and defined as carcinogenic and teratogenic factors. The research clearly indicates the inefficiency of phenol removal in conventional sewage treatment plants due to their high resistance to chemical and biological decomposition. Besides, the efficiency of its removal by physical methods is insufficient and does not guarantee that the water discharged into receivers will have the appropriate purity class. The use of durable and environmentally flexible materials such as enzymes is a promising technology for wastewater treatment containing phenolic compounds (Table 3).

To achieve effective degradation, Silva et al. [65] immobilized horseradish peroxidase on cashew polysaccharide, a natural polymer which, due to its renewable origin, significantly reduces the escalation of subsequent waste and, consequently, does not adversely affect the environment. Its attractiveness as a carrier of enzyme immobilization is enhanced by its very good solubility because its recovery is possible through simple precipitation reactions with polar organic solvents such as ethanol. Samples of actual textile wastewater and pollutants containing phenolic compounds such as catechol, phenol, bromophenols, and nitrophenols were taken at the wastewater treatment station (WTS) in Anápolis Agroindustrial District (DAIA) and Cia Hering in São Luís de Montes Belos, Goiás, Brazil. One hundred percent degradation efficiency was achieved with textile wastewater and $94 \%$ with WTS, whereas bromophenol was degraded in $40 \%$. The maximum reaction time for phenol removal was up to $30 \mathrm{~min}$, where for free enzyme, it was $90 \mathrm{~min}$. Consequently, the biodegradability or high non-toxicity of 
Table 3 Selected examples of phenol removal by immobilized oxidoreductases

\begin{tabular}{|c|c|c|c|c|c|}
\hline Enzymes & Support & $\begin{array}{l}\text { Immobilization } \\
\text { method }\end{array}$ & Target compound & $\begin{array}{l}\text { Reusability, storage } \\
\text { stability }\end{array}$ & Ref \\
\hline $\begin{array}{l}\text { Horseradish } \\
\text { peroxi- } \\
\text { dase }\end{array}$ & Cashew polysaccharide & $\begin{array}{l}\text { Adsorption/covalent } \\
\text { binding }\end{array}$ & Phenol & $\begin{array}{l}35 \% \text { after } 8 \text { cycles, } \\
70.5 \% \text { after } \\
30 \text { days }\end{array}$ & {$[65$} \\
\hline Laccase & Epoxy-functionalized silica & Covalent binding & $\begin{array}{l}\text { Phenol } \\
p \text {-Chlorophenol } \\
\text { Catechol }\end{array}$ & $61 \%$ after 5 cycles & {$[66]$} \\
\hline Tyrosinase & Functionalized magnetic nanobiocatalyst particles & Covalent binding & Phenol & $58 \%$ after 7 cycles & {$[67]$} \\
\hline Laccase & $\begin{array}{l}\text { Magnetic nanoparticles modified by amino-functionalized } \\
\text { ionic liquid using dialdehyde starch as cross-linker }\end{array}$ & Cross-linking & $\begin{array}{l}\text { Phenol, } \\
\text { 4-chlorophenol, } \\
\text { 2,4-dichlorophenol }\end{array}$ & $\begin{array}{l}83.5 \% \text { after } 6 \text { cycles, } \\
80 \% \text { after } 30 \text { days }\end{array}$ & {$[68]$} \\
\hline $\begin{array}{l}\text { Horseradish } \\
\text { peroxi- } \\
\text { dase }\end{array}$ & $\mathrm{Fe}_{3} \mathrm{O}_{4} /$ polyacrylonitrile magnetic nanofibers & Covalent binding & Phenol & $52 \%$ after 5 cycles & {$[69]$} \\
\hline $\begin{array}{l}\text { Horseradish } \\
\text { peroxi- } \\
\text { dase }\end{array}$ & Functionalized reduced graphene oxide & Covalent binding & Phenol & $\begin{array}{l}70 \% \text { after } 10 \text { cycles, } \\
97 \% \text { after } 35 \text { days }\end{array}$ & {$[70]$} \\
\hline $\begin{array}{l}\text { Horseradish } \\
\text { peroxi- } \\
\text { dase }\end{array}$ & Functionalized reduced graphene oxide & Covalent binding & Phenol & $100 \%$ after 60 days & {$[71]$} \\
\hline Peroxidase & Enzyme aggregates (RSVNP-CLEA) & Cross-linked & Phenol & $\begin{array}{l}50 \% \text { after } 5 \text { cycles, } \\
65 \% \text { after } 50 \text { days }\end{array}$ & {$[72]$} \\
\hline $\begin{array}{l}\text { Horseradish } \\
\text { peroxi- } \\
\text { dase }\end{array}$ & $\begin{array}{l}\text { Poly (vinyl alcohol)-polyacrylamide blend nanofiber } \\
\text { membrane }\end{array}$ & Covalent binding & Phenol & $60 \%$ after 4 cycles & {$[73]$} \\
\hline Laccase & Silica-coated magnetic nanoparticles & Covalent binding & Phenol & $50 \%$ after 8 cycles & {$[74]$} \\
\hline
\end{tabular}

cashew polysaccharide favors its commercialization in industrial biotechnological and medical sectors. Other well-proven carriers for enzyme immobilization and subsequent efficient degradation of phenols are inorganic carriers such as silica gels. Silicates are structurally stable, relatively cheap, and chemically resistant to organic solvents. Mohammadi et al. [66] examined laccase immobilization on silica particles functionalized with epoxy groups. Covalently immobilized laccase tripled its stability at extremely high temperatures, retaining $96 \%$ of its activity at $35^{\circ} \mathrm{C}$, where the free enzyme showed only $35 \%$ active at the same temperature. Finally, the degradation of phenol, $p$-chlorophenol, and catechol was carried out, achieving 76\%,60\%, and 95\% removal efficiency levels, respectively. Abdollahi et al. [67] in their research developed a nanobiocatalyst which is promising for micropollution degradation and an alternative to catalysts used in traditional wastewater treatment processes. To improve the catalytic activity, they modified magnetic iron oxide nanoparticles with APTES, and then before tyrosinase immobilization, the particles were further functionalized with 2,4,6-trichlorotriazine as an activating agent to obtain magnetic nanoparticles. They used the magnetic nanobiocatalyst (tyrosinase-MNP) thus constructed for the treatment of phenol-containing wastewater. It was proved that precise dosing of the nanobiocatalyst enables phenol degradation in a wide range of $\mathrm{pH}$ and temperature. Moreover, immobilized tyrosinase degraded highly concentrated $(2500 \mathrm{mg} / \mathrm{L})$ phenol with $70 \%$ efficiency. The nanobiocatalyst showed also a phenol degradation efficiency of $100 \%$ after the third re-use cycle and about $58 \%$ after the seventh cycle. In addition, immobilized tyrosinase was able to degrade phenol dissolved in real water samples of around $80 \%$ after incubation for $60 \mathrm{~min}$. Qiu et al. [68] combined the advantages of magnetic nanoparticles, ionic liquids, and dialdehyde starch to produce a new and highly efficient enzyme carrier. In the research, they immobilized laccase on magnetic nanoparticles modified with ionic liquid functionalized with amine groups using dialdehyde starch as a crosslinking agent $\left(\mathrm{Fe}_{3} \mathrm{O}_{4}\right.$-NIL-DAS). $\mathrm{Fe}_{3} \mathrm{O}_{4}$ as a magnetic nanomaterial is characterized by low toxicity, mature synthetic technology, fast separation from substrates, and good catalytic properties. However, it is quite problematic to immobilize the enzyme onto the parent $\mathrm{Fe}_{3} \mathrm{O}_{4}$; moreover, the carrier should provide the protein with high catalytic activity, physicochemical stability, or high substrate affinity. This is difficult to achieve when relying on a single inorganic carrier. It has been proven that ionic liquids as surface modifiers retain enzymatic activity, effectively increase stability, and improve reusability of the biomolecules. The prepared biocatalytic system eliminated $86 \%$ of phenol, and $94 \%$ of 4 -chlorophenol and $100 \%$ of 2,4-dichlorophenol, respectively. The system showed much better stability during storage and reuse, maintaining over $80 \%$ of activity after 30 days and $83.5 \%$ of initial 
activity after six catalytic cycles. Covalently immobilized laccase was more stable in the wider $\mathrm{pH}$ and temperature range; moreover, the increase in removal efficiency can be explained by the fact that $\mathrm{Fe}_{3} \mathrm{O}_{4}$-NIL-DAS provides a large number of sites capable of enzyme binding. As a result, laccase conformation is more stable and the high mobility of the chain makes the substrate more accessible for the enzyme. The biocatalytic system constructed in this way has great potential for the treatment of wastewater containing phenol. In another study, Li et al. [69] used horseradish peroxidase immobilized on magnetic nanofibers (MNFs) $\mathrm{Fe}_{3} \mathrm{O}_{4} / \mathrm{PAN}$ to treat wastewater from phenolic compounds. The combination of inorganic and organic materials allowed obtaining homogeneous nanofibers with strictly controlled nanostructure and maintaining different chemical characteristics of a given compound. The presented study proves that in the case of such a biocatalytic system, not only the process efficiency increase but also the stability and reusability improve. Immobilized peroxidase degraded phenol in $85 \%$, while the degradation activity after 5 cycles still oscillated at a high level of $52 \%$. One hundred percent degradation of phenol at high concentration $(2500 \mathrm{mg} / \mathrm{L})$ was obtained by Vineh et al. [70] who performed covalent immobilization of horseradish peroxidase on functionalized, reduced graphene oxide using glutaraldehyde as a cross-linking agent. Graphene oxide is characterized by a great number of functional groups such as thick carboxyl, hydroxyl, or epoxy, which not only supports their solubility in water or polar solvents but also ultimately affects the efficiency of degradation by the immobilized enzyme. The study confirmed the effectiveness of covalent immobilization of horseradish peroxidase on reduced graphene oxide, which proved to be an excellent substrate to support the enzyme before inactivation of the biocatalyst. Besides, a significant improvement in all kinetic parameters was observed, and the thermal stability and catalytic activity were enhanced. Finally, covalently immobilized peroxidase, in addition to total phenol degradation, showed also $70 \%$ activity retention after 10 cycles and $96 \%$ of activity after 35 days of storage.

\section{Removal of Phenol Derivatives}

Phenol derivatives, like phenol itself, are recognized as a hazardous environmental pollutant that can be considered a risk to humans, animals, and aquatic organisms. This is due to the relatively high toxicity of these compounds, even at low concentrations. According to the International Programme on Chemical Safety, organic compounds from many industries can be fatal to living organisms, due to the possibility of damaging the nervous system, heart, kidneys, and liver [33]. Therefore, various methods of water and wastewater treatment are used to remove these substances among which biological/ enzymatic methods appear to be more cost-effective and ecofriendly. Additionally, in order to minimize free enzyme limitations, immobilized enzymes are very often used in purification processes (Table 4).

One of the most common phenol derivatives with two hydroxyphenyl groups are bisphenols, e.g., bisphenol A, bisphenol S, and bisphenol F. However, among them, the most popular is bisphenol $\mathrm{A}$, which has been used in the production of plastics for years. Moreover, scientists have proved that it has a harmful effect on the endocrine system [75]. Research has shown that it is possible to degrade bisphenols to less toxic derivatives using laccases. For this purpose, Brugnari et al. [76] used laccase from Pleurotus ostreatus immobilized onto monoaminoethyl- $N$-aminoethyl agarose, which enabled improvement of thermal and storage stability of the enzyme, as well as its efficiency in the degradation of bisphenol A. Laccase in free form is characterized by retention of $40 \%$ initial activity after 40 days of storage. In contrast, the immobilization of the enzyme allowed storage for 40 days and 170 days with $80 \%$ and $70 \%$ of the initial activity retention, respectively. Additionally, the immobilized laccase enables to carry out 15 catalytic cycles with over $90 \%$ efficiency in the removal of phenolic contamination. The adsorption immobilization of laccase from Trametes versicolor was also by Taghizadeh et al. [77], who tested sodium zeolite $\mathrm{Y}$ and its modifications as supports. The application of desilicated zeolite improved the stability of laccase and made it possible to carry out the biodegradation process of bisphenol A with the efficiency of over $85 \%$. However, it should be mentioned that the process was conducted for a very short period of time reaching $1 \mathrm{~h}$. Nevertheless, the proposed biocatalytic system is not as stable as the one mentioned above, since about $59 \%$ of the initial enzymatic activity was retained after 14 days of storage. Lassouane et al. [78] carried out immobilization of the laccase from Trametes pubescens using two simultaneous methods: cross-linking with glutaraldehyde and entrapment into $\mathrm{Ca}$-alginate beads, which resulted in a 7fold reduction in enzyme leakage compared to simple entrapment immobilization. The prepared biocatalytic system allowed for the biodegradation of bisphenol A at a concentration of $20 \mathrm{mg} / \mathrm{L}$ at $\mathrm{pH} 5$ and $30^{\circ} \mathrm{C}$. Within $2 \mathrm{~h}$, almost $100 \%$ efficiency of pollutant removal was achieved. Moreover, this biocatalyst was able to work for the next 10 catalytic cycles with the process efficiency above $70 \%$. High removal efficiencies disposed scientists to check whether any part of bisphenol A was adsorbed onto alginate beads. The tests showed that only immobilized laccase is responsible for the removal of the contamination. In some scientific works, researchers are trying to biodegrade more pollutants from bisphenol group using one biocatalytic system. For example, Zdarta et al. [79] designed a system to remove three bisphenols: bisphenol A, bisphenol $\mathrm{F}$, and bisphenol S. Laccase from Trametes versicolor was immobilized on a novel biopolymer material-Hippospongia communis sponginbased scaffold. Almost 100\% removal efficiency of bisphenol 
Table 4 Selected examples of phenol derivatives removed by immobilized oxidoreductases

\begin{tabular}{|c|c|c|c|c|c|}
\hline Enzymes & Support & $\begin{array}{l}\text { Immobilization } \\
\text { method }\end{array}$ & Target compound & $\begin{array}{l}\text { Reusability, storage } \\
\text { stability }\end{array}$ & Ref. \\
\hline $\begin{array}{l}\text { Laccase from } \\
\text { Trametes versicolor }\end{array}$ & $\begin{array}{l}\text { Poly (styrene-co- } \\
\text { divinylbenzene)- } \\
\text { graft-poly } \\
\text { (cyclic-carbonate } \\
\text { methacrylate) }\end{array}$ & $\begin{array}{l}\text { Covalent } \\
\text { binding }\end{array}$ & Bisphenol A & $53 \%$ after 10 cycles & [75] \\
\hline $\begin{array}{l}\text { Laccase from } \\
\quad \text { Pleurotus ostreatus }\end{array}$ & MANAE-agarose & Adsorption & Bisphenol A & $\begin{array}{l}90 \% \text { after } 15 \text { cycles, } \\
70 \% \text { after } 170 \text { days }\end{array}$ & [76] \\
\hline $\begin{array}{l}\text { Laccase from } \\
\quad \text { Trametes versicolor }\end{array}$ & Sodium zeolite $\mathrm{Y}$ & Adsorption & Bisphenol A & $60 \%$ after 14 days & [77] \\
\hline $\begin{array}{l}\text { Laccase from } \\
\quad \text { Trametes pubescens }\end{array}$ & $\mathrm{Ca}-$ alginate beads & Cross-linking & Bisphenol A & $\begin{array}{l}70 \% \text { after } 10 \text { cycles, } \\
90 \% \text { after } 35 \text { days }\end{array}$ & [78] \\
\hline $\begin{array}{l}\text { Laccase from } \\
\quad \text { Trametes versicolor }\end{array}$ & $\begin{array}{l}\text { Hippospongia communis } \\
\text { spongin scaffolds }\end{array}$ & Adsorption & $\begin{array}{l}\text { Bisphenol A } \\
\text { Bisphenol F } \\
\text { Bisphenol S }\end{array}$ & $80 \%$ after 50 days & [79] \\
\hline Laccase from Aspergillus & $\begin{array}{l}\text { Peanut shell and wheat } \\
\text { straw }\end{array}$ & Cross-linking & $\begin{array}{l}\text { Isoproturon, atrazine, } \\
\text { prometryn, mefenacet, } \\
\text { penoxsulam, nitenpyram, } \\
\text { prochloraz, } \\
\text { pyrazosulfuron-ethyl, } \\
\text { bensulfuron-methyl }\end{array}$ & - & [80] \\
\hline $\begin{array}{l}\text { Laccase from Pycnoporus } \\
\text { sanguineus and Trametes } \\
\text { versicolor }\end{array}$ & $\begin{array}{l}\text { Multichannel ceramic } \\
\text { membrane }\end{array}$ & Cross-linking & Bisphenol A & - & [81] \\
\hline Laccase from Trametes versicolor & Chitosan beads & $\begin{array}{l}\text { Covalent } \\
\text { binding/ } \\
\text { cross-linking }\end{array}$ & Bisphenol A & $\begin{array}{l}71 \% \text { after } 10 \text { cycles, } \\
90 \% \text { after } 28 \text { days }\end{array}$ & [82] \\
\hline Laccase from Trametes versicolor & $\begin{array}{l}\text { Metal-organic framework } \\
\text { HKUST-1 }\end{array}$ & Encapsulation & Bisphenol A & $\begin{array}{l}78 \% \text { after } 10 \text { cycles, } \\
70 \% \text { after } 30 \text { days }\end{array}$ & [83] \\
\hline Laccase from Trametes hirsuta & $\begin{array}{l}\text { Amino-functionalized } \\
\text { magnetic } \mathrm{Fe}_{3} \mathrm{O}_{4} \\
\text { nanoparticles }\end{array}$ & Cross-linking & Bisphenol A & $30 \%$ after 6 cycles & [84] \\
\hline
\end{tabular}

$\mathrm{A}$ and bisphenol $\mathrm{F}$ was obtained under the following conditions: $\mathrm{pH} 5$ at $30^{\circ} \mathrm{C}$ and $\mathrm{pH} 5$ at $40^{\circ} \mathrm{C}$, respectively. However, over $40 \%$ of bisphenol $\mathrm{S}$ was degraded at $\mathrm{pH} 4$ and $30^{\circ} \mathrm{C}$. It should also be noted that immobilized laccase retained about $90 \%$ of initial activity after 20 days and over $80 \%$ after 50 days of storage at $4^{\circ} \mathrm{C}$.

Also among pesticides, compounds from the group of phenol derivatives can be found. Chen et al. [80] undertook the degradation of nine different pesticides, but to ensure high efficiency, they opted for combined methods: biodegradation with laccase immobilized on two biosorbents. Peanut shells and wheat straw were used as supports, and to the reaction system, syringaldehyde was also added, which was responsible for improving the catalytic properties of laccase. The first removal tests were carried out on pesticides present in the water within 3 days. In the system with laccase immobilized on peanut shells, it was possible to degrade $54.5 \%$ of the pollution, whereas when wheat straw was used, the reaction efficiency was $65.9 \%$. In the next part of the research, the source of the contamination was changed. Biodegradation of pesticides from the soil for 7 days removed about 20 to $92 \%$ of the pollutants using both peanut shell system and wheat straw system. Large discrepancy of results is due to the differences in pesticide resistance to enzymatic treatment. Nevertheless, it should be emphasized that biodegradation in combination with adsorption has a very high potential and can be an effective solution to the problem of pollution in both water and soil.

Lignin is a common biopolymer in which the monomers are organic compounds derived from phenolic alcohols. Its chemical structure is very extensive and complicated, which prevents its wider application. Therefore, the aim is to convert lignin to compounds with lower molecular weight. For this, laccase is used as it allows the degradation of the biopolymer. Chen et al. [85] immobilized enzyme on magnetic nanoparticles, which additionally facilitate easy separation of the biocatalyst from the reaction system in the final stage of the process. Using immobilized laccase, it was possible to degrade almost $100 \%$ of model lignin compounds. However, after 8 consecutive catalytic cycles, only $40 \%$ of the initial enzyme activity was retained. Nevertheless, the conducted tests would have to be repeated using a real solution to check whether the proposed biocatalytic system would be equally effective. As can be seen from the abovementioned results, laccase is actually necessary in the degradation of phenolic derivatives and in the removal of these pollutants from water, sewage, or soil. 


\section{Challenges and Future Prospects}

Investigation of oxidoreductase immobilization shows great application perspectives for wastewater treatment. However, there are several obstacles that have to be solved in the near future to facilitate transfer of laboratory-scale developments into larger scale. We have summarized, in our opinion, the most crucial issues that limit practical applications of the oxidoreductase-based biocatalytic systems and require further investigation and novel solutions.

- Reduction of production costs of enzymes by developing of novel technologies or by optimization of currently existing processes.

- Improvement of the enzyme stability at harsh process conditions and its reusability by application of novel immobilization approaches. Process optimization in order to produce highly active and long-term stable biocatalytic systems

- Application of a novel, tailor-made support materials to promote enzyme activity and its applicability. Proper selection of the support materials to provide protection for the biomolecule and suitable enzyme microenvironment as well as to meet the process requirements.

- Optimization of the biodegradation process in order to achieve high removal rate. Selection of the process conditions and applicability of the biocatalytic systems in various water bodies, including real water and wastewater.

- Detail characterization of the biodegradation products in order to evaluate effective methods of their separation and examination of the toxicity of the post-reaction mixture. Characterization of the catalytic pathways of the biodegradation reaction to determine bottle neck of the reaction and examine by-products.

- Application of the enzymatic reactors and enzymatic membrane bioreactors containing immobilized biocatalysts as catalytic beads for continuous treatment of model and real water solutions. Characterization of the effect of process conditions on removal efficiency.

- Evaluation of a novel and promising approaches for more efficient treatment of pollutants, such as simultaneous adsorption and biodegradation or enzymatic conversion supported by photocatalysis.

- Development of solutions facilitating transfer of laboratory- or small-scale procedures into larger scale to allow real wastewater treatment by using immobilized oxidoreductases.

\section{Conclusions and Final Remarks}

In summary, rapid development of the various branches of industry generates huge amounts of toxic phenolic compounds that are presented in water and wastewater. Among various recently developed approaches for removal of the abovementioned compounds, use of free and particularly immobilized enzymes is extremely promising. Enzymatic techniques based on use of immobilized oxidoreductases (mainly laccases, tyrosinases, and peroxidases) offer several advantages including low cost, sustainability, and/or mild process conditions. Immobilized oxidoreductases, due to their relatively low substrate specificity, are capable of effective conversion of numerous phenol and phenolic derivatives including pharmaceuticals, estrogens, bisphenols, or dyes with removal rates usually exceeding $90 \%$. Further, enzymatic treatment facilitates reduction of estrogenic activity and toxicity by generation of low-toxicity final products of conversion. Although further studies are still highly required to optimize immobilization and bioremediation conditions and to reduce cost of the process, the application of immobilized biocatalysts for removal of phenolic pollutants is expected to be a breakthrough in the future.

Funding This work was supported by the National Science Centre, Poland, under the research grant number 2019/35/D/ST8/02087.

\section{Compliance with Ethical Standards}

Conflict of Interest Authors declare no conflict of interest.

Human and Animal Rights and Informed Consent This article does not contain any studies with human or animal subjects performed by any of the authors.

Open Access This article is licensed under a Creative Commons Attribution 4.0 International License, which permits use, sharing, adaptation, distribution and reproduction in any medium or format, as long as you give appropriate credit to the original author(s) and the source, provide a link to the Creative Commons licence, and indicate if changes were made. The images or other third party material in this article are included in the article's Creative Commons licence, unless indicated otherwise in a credit line to the material. If material is not included in the article's Creative Commons licence and your intended use is not permitted by statutory regulation or exceeds the permitted use, you will need to obtain permission directly from the copyright holder. To view a copy of this licence, visit http://creativecommons.org/licenses/by/4.0/.

\section{References}

1. Aleya L, Uddin MS. Environmental pollutants and the risk of neurological disorders. Environ Sci Pollut Res. 2020;27:44657-8. https://doi.org/10.1007/s11356-020-11272-3.

2. Bilal M, Iqbal HMN, Barceló D. Perspectives on the feasibility of using enzymes for pharmaceutical removal in wastewater. Handb. Environ. Chem. 2020;172:1-25. https://doi.org/10.1007/698 2020_661.

3. Parra-Saldivar R, Castillo-Zacarías C, Bilal M, Iqbal HMN, Barceló D. Sources of pharmaceuticals in water. Handb. Environ. Chem. 2020;103:33-47. https://doi.org/10.1007/698_2020_623. 
4. Kallel A, Ksibi M, Dhia HB, Khelifi N. Pollutant removal and the health effects of environmental pollution. Environ Sci Pollut Res. 2020;27:23375-8. https://doi.org/10.1007/s11356-020-08775-4.

5. Bilal M, Mehmood S, Rasheed T, Iqbal HM. Antibiotics traces in the aquatic environment: persistence and adverse environmental impact. Curr Opin Environ Sci Health. 2020;13:68-74. https:// doi.org/10.1016/j.coesh.2019.11.005.

6. Bilal M, Iqbal HMN. Persistence and impact of steroidal estrogens on the environment and their laccase assisted removal. Sci Total Environ. 2019;690:447-59. https://doi.org/10.1016/j.scitotenv. 2019.07.025.

7. Ho KC, Teow YH, Sum JY, Ng ZJ, Mohammad AW. Water pathways through the ages: integrated laundry wastewater treatment for pollution prevention. Sci Total Environ. 2021;760:143966. https:// doi.org/10.1016/j.scitotenv.2020.143966.

8. Wang Z, Zhang Y, Li K, Sun Z, Wang J. Enhanced mineralization of reactive brilliant red X-3B by UV-driven photocatalytic membrane contact ozonation. J. Hazard. Mater. 2020;391:122-94. https://doi.org/10.1016/j.jhazmat.2020.122194.

9. Kadam RL, Kim Y, Gaikwad S, Chang M. Catalytic decolorization of Rhodamine B, Congo Red, and Crystal Violet dyes, with a novel niobium oxide anchored molybdenum (Nb-O-Mb). Catalysts. 2020;10:491. https://doi.org/10.3390/catal10050491.

10. Singh RL, Singh PK, Singh RP. Enzymatic decolorization and degradation of azo dyes - a review. Int. Biodeter. Biodegr. 2015;104: 10421-31. https://doi.org/10.1016/j.ibiod.2015.04.027.

11. Saleh IA, Zouari N, Al-Ghouti MA. Removal of pesticides from water and wastewater: chemical, physical and biological treatment approaches. Environ Technol Innov. 2020;19:101026. https://doi. org/10.1016/j.eti.2020.101026.

12. Stadlmair LF, Letzel T, Drewes JE, Grassmann J. Enzymes in removal of pharmaceuticals from wastewater: a critical review of challenges, applications and screening methods for their selection. Chemosphere. 2018;205:649-61. https://doi.org/10.1016/j. chemosphere.2018.04.142.

13. Ivanov V, Stabnikov V, Stabnikova O, Kawasaki S. Environmental safety and biosafety in construction biotechnology. World J Microb Biot. 2019;35:26. https://doi.org/10.1007/s11274-019-2598-9.

14. Jager CM, Croft AK. Anaerobic radical enzymes for biotechnology. Chem Bio Eng Rev. 2018;5:143-62. https://doi.org/10.1002/ cben.201800003.

15. Jesionowski T, Zdarta J, Krajewska B. Enzyme immobilization by adsorption: a review. Adsorption. 2014;20:801-21. https://doi.org/ 10.1007/s10450-014-9623-y.

16. Zdarta J, Meyer AS, Jesionowski T, Pinelo M. Multi-faceted strategy based on enzyme immobilization with reactant adsorption and membrane technology for biocatalytic removal of pollutants: a critical review. Biotechnol Adv. 2019;3:107401. https://doi.org/10. 1016/j.biotechadv.2019.05.007.

17. Li LJ, Xia WJ, Ma GP, Chen YL, Ma YY. A study on the enzymatic properties and reuse of cellulase immobilized with carbon nanotubes and sodium alginate. AMB Expr. 2019;9:112. https:// doi.org/10.1186/s13568-019-0835-0.

18. Bilal M, Adeel M, Rasheed T, Zhao Y, Iqbal HMN. Emerging contaminants of high concern and their enzyme-assisted biodegradation - a review. Environ Int. 2019;124:336-53. https://doi.org/ 10.1016/j.envint.2019.01.011.

19. Quesada HB, Alves Baptista AT, Cusioli LF, Seibert D, de Oliveira $\mathrm{BC}$, Bergamasco R. Surface water pollution by pharmaceuticals and an alternative of removal by low-cost adsorbents: a review. Chemosphere. 2019;222:766-80. https://doi.org/10.1016/j. chemosphere.2019.02.009.

20. Saeid S, Tolvanen P, Kumar N, Eränen K, Peltonen J, Peurla M, et al. Advanced oxidation process for the removal of ibuprofen from aqueous solution: a non-catalytic and catalytic ozonation study in a semi-batch reactor. Appl. Catal. B. 2018;230:77-90. https://doi. org/10.1016/j.apcatb.2018.02.021.

21. Ontañon OM, González PS, Barros GG, Agostini E. Improvement of simultaneous $\mathrm{Cr}$ (VI) and phenol removal by an immobilised bacterial consortium and characterisation of biodegradation products. New Biotechnol. 2016;37:172-9. https://doi.org/10.1016/j. nbt.2017.02.003.

22. Bhatia D, Sharma NR, Singh J, Kanwar RS. Biological methods for textile dye removal from wastewater: a review. Crit Rev Env Sci Tec. 2017;47:1836-76. https://doi.org/10.1080/10643389.2017. 1393263.

23. Meena M, Sonigra P, Yadav G. Biological-based methods for the removal of volatile organic compounds (VOCs) and heavy metals. Environ Sci Pollut Res. 2020;28:2485-508. https://doi.org/10. 1007/s11356-020-11112-4.

24. Hassan Z, Ali S, Rizwan M, Ibrahim M, Nafees M, Waseem M. Role of bioremediation agents (bacteria, fungi, and algae) in alleviating heavy metal toxicity. Probiotics in Agroecosystem. 2017: 517-37. https://doi.org/10.1007/978-981-10-4059-7_27.

25. Zhu Y, Wang W, Ni J, Hu B. Cultivation of granules containing anaerobic decolorization and aerobic degradation cultures for the complete mineralization of azo dyes in wastewater. Chemosphere. 2020;246:125753. https://doi.org/10.1016/j.chemosphere.2019. 125753 .

26. Thwaites BJ, Short MD, Stuetz RM, Reeve PJ, Alvarez Gaitan J-P, Dinesh N, et al. Comparing the performance of aerobic granular sludge versus conventional activated sludge for microbial log removal and effluent quality: implications for water reuse. Water Res. 2018;145:442-53. https://doi.org/10.1016/j.watres.2018.08.038.

27. Kaushal J, Mehandia S, Singh G, Raina A, Arya SK. Catalase enzyme: application in bioremediation and food industry. Biocatal Agric Biotechnol. 2018;16:192-9. https://doi.org/10.1016/j.bcab. 2018.07.035.

28. Barber EA, Liu Z, Smith SR. Organic contaminant biodegradation by oxidoreductase enzymes in wastewater treatment. Microorganisms. 2020;8:122. https://doi.org/10.3390/ microorganisms 8010122 .

29. Bilal M, Ashraf SS, Cui J, Lou WY, Franco M, Mulla SI, et al. Harnessing the biocatalytic attributes and applied perspectives of nanoengineered laccases - a review. Int. J. Biol. Macromol. 2021;166:352-73. https://doi.org/10.1016/j.ijbiomac.2020.10.195.

30. Morsi R, Bilal M, Iqbal HM, Ashraf SS. Laccases and peroxidases: the smart, greener and futuristic biocatalytic tools to mitigate recalcitrant emerging pollutants. Sci. Total Environ. 2020;714:136-572. https://doi.org/10.1016/j.scitotenv.2020.136572.

31. Alneyadi AH, Rauf MA, Ashraf SS. Oxidoreductases for the remediation of organic pollutants in water - a critical review. Crit Rev Biotechnol. 2018;38:1-18. https://doi.org/10.1080/07388551. 2017.1423275.

32. Liu Z, Smith SR. Enzyme recovery from biological wastewater treatment. Waste Biomass Valor. 2020. https://doi.org/10.1007/ s12649-020-01251-7.

33. Jun LY, Jon LS, Mubarak NM, Bing CHH, Pan S, Danquah MK, et al. An overview of immobilized enzyme technologies for dye and phenolic removal from wastewater. J Environ Chem Eng. 2019;7: 102961. https://doi.org/10.1016/j.jece.2019.102961.

34. Zdarta J, Meyer AS, Jesionowski T, Pinelo M. Developments in support materials for immobilization of oxidoreductases: a comprehensive review. Adv Colloid Interface Sci. 2018;258:1-20. https:// doi.org/10.1016/j.cis.2018.07.004.

35. Bilal M, Iqbal HMN, Barceló D. Mitigation of bisphenol A using an array of laccase-based robust bio-catalytic cues - a review. Sci Total Environ. 2019;689:160-77. https://doi.org/10.1016/j.scitotenv. 2019.06.403.

36. Ba S, Haroune L, Soumano L, Bellenger JP, Jones JP, Cabana H. A hybrid bioreactor based on insolubilized tyrosinase and laccase 
catalysis and microfiltration membrane remove pharmaceuticals from wastewater. Chemosphere. 2018;201:749-55. https://doi.org/ 10.1016/j.chemosphere.2018.03.022.

37. Zdarta J, Luong NN, Jankowska K, Jesionowski TL, DN. A contemporary review of enzymatic applications in the remediation of emerging estrogenic compounds. Crit. Rev. Environ. Sci. Technol. 2021:1-30. https://doi.org/10.1080/10643389.2021.1889283.

38. Bilal M, Rasheed T, Iqbal HMN, Yan Y. Peroxidases-assisted removal of environmentally-related hazardous pollutants with reference to the reaction mechanisms of industrial dyes. Sci Total Environ. 2018;644:1-13. https://doi.org/10.1016/j.scitotenv.2018. 06.274 .

39. Yeow PK, Wong SW, Hadibarata T. Removal of azo and anthraquinone dye by plant biomass as adsorbent. Biointerface Res Appl Chem. 2021;11:8218-32. https://doi.org/10.33263/BRIAC111. 82188232.

40. Yaseen DA, Scholz M. Textile dye wastewater characteristics and constituents of synthetic effluents: a critical review. Int J Environ Sci Technol. 2019;16:1193-226. https://doi.org/10.1007/s13762018-2130-z.

41. Berradi M, Hsissou R, Khudhair M, Assouag M, Cherkaoui O, El Bachiri A, et al. Textile finishing dyes and their impact on aquatic environs. Heliyon. 2019;5:e02711. https://doi.org/10.1016/j. heliyon.2019.e 02711.

42. Bilal M, Iqbal HM. Microbial peroxidases and their unique catalytic potentialities to degrade environmentally related pollutants. In Microbial Technology for Health and Environment. 2020;22:124. https://doi.org/10.1007/978-981-15-2679-4_1.

43. Parra-Arroyo L, Parra-Saldivar R, Ramirez-Mendoza RA, Keshavarz T, Iqbal HMN. Laccase-assisted cues: state-of-the-art analytical modalities for detection, quantification, and redefining "removal" of environmentally related contaminants of high concern. In: Schlosser D. (eds) Laccases in bioremediation and waste valorisation. Microbiology Monographs. 2020:33. https://doi.org/ 10.1007/978-3-030-47906-0 7.

44. Zamora MH, Jeronimo FM. Exposure to the azo dye Direct Blue 15 produces toxic effects on microalgae, cladocerans, and zebrafish embryos. Ecotoxicol. 2019;28:890-902. https://doi.org/10.1007/ s10646-019-02087-1.

45. Fernandes FH, Umbuzeiro GA, Salvadori DMF. Genotoxicity of textile dye C.I. Disperse Blue 291 in mouse bone marrow. Mutat Res Genet Toxicol Environ Mutagen. 2019;837:48-51. https://doi. org/10.1016/j.mrgentox.2018.10.003.

46. Antecka K, Zdarta J, Siwińska-Stefańska K, Sztuk G, Jankowska E, Oleskowicz-Popiel P, et al. Synergistic degradation of dye wastewaters using binary or ternary oxide systems with immobilized laccase. Catalysts. 2018;8:402. https://doi.org/10.3390/ catal8090402.

47. Yavaşer R, Karagözler AA. Laccase immobilized polyacrylamidealginate cryogel: a candidate for treatment of effluents. Process Biochem. 2021;101:137-46. https://doi.org/10.1016/j.procbio. 2020.11.021.

48. Sondhi S, Kaur R, Kaur S, Kaur PS. Immobilization of laccaseABTS system for the development of a continuous flow packed bed bioreactor for decolorization of textile effluent. Int J Biol Macromol. 2018;117:1093-100. https://doi.org/10.1016/j. ijbiomac.2018.06.007.

49. Bello-Gil D, Roig-Molina E, Fonseca J, Sarmiento-Ferrandez MD, Ferrandiz M, Franco E, et al. An enzymatic system for decolorization of wastewater dyes using immobilized $\mathrm{CueO}$ laccase-like multicopper oxidase on poly-3-hydroxybutyrate. Microb Biotechnol. 2018;11:881-92. https://doi.org/10.1111/1751-7915. 13287.

50. Khazravi MS, Bahmaei M, Olya ME, Etezad SM. Application of a new self-cleaning filter for colored wastewaters treatment using laccase enzyme immobilized on activated carbon powder and fiber. PCCC. 2019;12:39-56. https://doi.org/10.30509/pccc.2019.81492.

51. Jankowska K, Zdarta J, Grzywaczyk A, Degórska O, KijeńskaGawrońska E, Pinelo M, et al. Horseradish peroxidase immobilised onto electrospun fibres and its application in decolourisation of dyes from model sea water. Process Biochem. 2021;102:10-21. https://doi.org/10.1016/j.procbio.2020.11.015.

52. Bilal M, Asgher M, Iqbal M, Hu H, Zhang X. Chitosan beads immobilized manganese peroxidase catalytic potential for detoxification and decolorization of textile effluent. Int J Biol Macromol. 2016;89:181-9. https://doi.org/10.1016/j.ijbiomac.2016.04.075.

53. Siddeeg SM, Tahoon MA, Mnif W, Ben RF. Iron oxide/chitosan magnetic nanocomposite immobilized manganese peroxidase for decolorization of textile wastewater. Processes. 2020;8:5. https:// doi.org/10.3390/pr8010005.

54. Naghdi M, Taheran M, Brar SK, Kermanshahi-Pour A, Verma M, Surampalli RY. Removal of pharmaceutical compounds in water and wastewater using fungal oxidoreductase enzymes. Environ Pollut. 2018;234:1900213. https://doi.org/10.1016/j.envpol.2017. $11.060,213$

55. Taheran M, Naghdi M, Brar SK, Knystautas EJ, Verma M, Surampalli RY. Covalent immobilization of laccase onto nanofibrous membrane for degradation of pharmaceutical residues in water. ACS Sustain Chem Eng. 2017;5:10430-8. https://doi.org/ 10.1021/acssuschemeng.7b02465.

56. Naghdi M, Taheran M, Brar SK, Kermanshahi-Pour A, Verma M, Surampalli RY. Immobilized laccase on oxygen functionalized nanobiochars through mineral acids treatment for removal of carbamazepine. Sci Total Environ. 2017;584-5:393-401. https://doi. org/10.1016/j.scitotenv.2017.01.021.

57. Wen X, Zeng Z, Du C, Huang D, Zeng G, Xiao R, et al. Immobilized laccase on bentonite-derived mesoporous materials for removal of tetracycline. Chemosphere. 2019;222:865-71. https://doi.org/10.1016/j.chemosphere.2019.02.020.

58. García-Delgado C, Eymar E, Camacho-Arévalo R, Petruccioli M, Crognale S, D'Annibale A. Degradation of tetracyclines and sulfonamides by stevensite-and biochar-immobilized laccase systems and impact on residual antibiotic activity. J Chem Technol Biotechnol. 2018;93:3394-409. https://doi.org/10.1002/jctb.5697.

59. Jeong D, Choi K-Y. Biodegradation of tetracycline antibiotic by laccase biocatalyst immobilized on chitosan-tripolyphosphate beads. Appl Biochem Microbiol. 2020;56:306-12. https://doi.org/ $10.1134 / \mathrm{s} 0003683820030047$.

60. Xu R, Si Y, Li F, Zhang B, et al. Enzymatic removal of paracetamol from aqueous phase: horseradish peroxidase immobilized on nanofibrous membranes. Environ Sci Pollut Res. 2014;22:383846. https://doi.org/10.1007/s11356-014-3658-1.

61. Becker D, Rodriguez-Mozaz S, Insa S, Schoevaart R, Barceló D, de Cazes M, et al. Removal of endocrine disrupting chemicals in wastewater by enzymatic treatment with fungal laccases. Org Process Res Dev. 2017;21:480-91. https://doi.org/10.1021/acs. oprd.6b00361.

62. Garcia LF, Lacerda MFAR, Thomaz DV, Golveia JCS, das Gra M PC, Gila ES, et al. Optimization of laccase-alginate-chitosan-1016 based matrix toward 17a-ethinylestradiol removal. Prep Biochem Biotech. 2019;49:375-83. https://doi.org/10.1080/10826068.2019. 1573195.

63. Lacerda MFAR, Lopes FM, Sartoratto A, Ponezi AN, Thomaz DV, Schimidt F, et al. Stability of immobilized laccase on Luffa cylindrica fibers and assessment of synthetic hormone degradation. Prep Biochem Biotechnol. 2018;49:1-6. https://doi.org/10.1080/ 10826068.2018.1525568.

64. Yusnidar Y. The utilization of laccase - functionalized graphene oxide as an effective biodegradation of pharmaceutical industry waste: diclofenac and ibuprofen. Sys Rev Pharm. 2020;11. https:// doi.org/10.5530/srp.2020.1.67. 
65. Silva T, Borges LL, Barboza e Souza ER, Caramori SS. Synthesis of immobilized biocatalysts for wastewater decontamination. Polímeros. 2019;29:4. https://doi.org/10.1590/0104-1428.08918.

66. Mohammadi M, Ashabi MA, Salehi P, Yousefi M, Nazari M, Brask J. Immobilization of laccase on epoxy-functionalized silica and its application in biodegradation of phenolic compounds. Int J Biol Macromol. 2018;109:443-7. https://doi.org/10.1016/j.ijbiomac. 2017.12.102

67. Abdollahi K, Yazdani F, Panahi R, Mokhtarani B. Biotransformation of phenol in synthetic wastewater using the functionalized magnetic nano-biocatalyst particles carrying tyrosinase. 3 Biotech. 2018;8. https://doi.org/10.1007/s13205-018-1445-2.

68. Qiu X, Wang Y, Xue Y, Li W, Hu Y. Laccase immobilized on magnetic nanoparticles modified by amino-functionalized ionic liquid via dialdehyde starch for phenolic compounds biodegradation. Chem Eng J. 2020;391:123564. https://doi.org/10.1016/j.cej.2019. 123564.

69. Li J, Chen X, Xu D, Pan K. Immobilization of horseradish peroxidase on electrospun magnetic nanofibers for phenol removal. Ecotoxicol Environ Saf. 2019;170:716-21. https://doi.org/10. 1016/j.ecoenv.2018.12.043

70. Vineh MB, Saboury AA, Poostchi AA, Rashidi AM, Parivar K. Stability and activity improvement of horseradish peroxidase by covalent immobilization on functionalized reduced graphene oxide and biodegradation of high phenol concentration. Int J Biol Macromol. 2018;106:1314-22. https://doi.org/10.1016/j.ijbiomac. 2017.08.133

71. Sellami K, Couvert A, Nasrallah N, Maachi R, Tandjaoui N, Abouseoud M, et al. Bio-based and cost effective method for phenolic compounds removal using cross-linked enzyme aggregates. J Hazard Mater. 2021;403:124021. https://doi.org/10.1016/j. jhazmat.2020.124021.

72. Moreira MT, Moldes-Diz Y, Feijoo S, Eibes G, Lema JM, Feijoo G. Formulation of laccase nanobiocatalysts based on ionic and covalent interactions for the enhanced oxidation of phenolic compounds. Appl Sci. 2017;7:851. https://doi.org/10.3390/ app7080851.

73. Temocin Z, Inal M, Gokgoz M, Yigitoglu M. Immobilization of horseradish peroxidase on electrospun poly (vinyl alcohol)-polyacrylamide blend nanofiber membrane and its use in the conversion of phenol. Polym Bull. 2018;75:1843-65. https://doi.org/10.1007/ s00289-017-2129-5.

74. Alver E, Metin AÜ. Chitosan based metal-chelated copolymer nanoparticles: laccase immobilization and phenol degradation studies. Int Biodeterior Biodegradation. 2017;125:235-42. https://doi. org/10.1016/j.ibiod.2017.07.012.

75. Bayramoglu G, Karagoz B, Arica MY. Cyclic-carbonate functionalized polymer brushes on polymeric microspheres: immobilized laccase for degradation of endocrine disturbing compounds. J Ind Eng Chem. 2018;60:407-17. https://doi.org/10.1016/j.jiec.2017. 11.028 .
76. Brugnari T, Gimenez Pereira M, Bubna GA, de Freitas EN, Contato AG, Carvalho Gomes Correa R, et al. A highly reusable MANAEagarose-immobilized Pleurotus ostreatus laccase for degradation of bisphenol A. Sci Total Environ. 2018;634:1346-51. https://doi.org/ 10.1016/j.scitotenv.2018.04.051.

77. Taghizadeh T, Talebian-Kiakalaieh A, Jahandar H, Amin M, Tarighi S, Faramarzi MA. Biodegradation of bisphenol A by the immobilized laccase on some synthesized and modified forms of zeolite Y. J Hazard Mater. 2020;386:121950. https://doi.org/10. 1016/j.jhazmat.2019.121950.

78. Lassouane F, Ait-Amar H, Amrani S, Rodriguez-Couto S. A promising laccase immobilization approach for bisphenol A removal from aqueous solutions. Bioresour Technol. 2019;271:360-7. https://doi.org/10.1016/j.biortech.2018.09.129.

79. Zdarta J, Antecka K, Frankowski R, Zgoła-Grześkowiak A, Ehrlich $\mathrm{H}$, Jesionowski T. The effect of operational parameters on the biodegradation of bisphenols by Trametes versicolor laccase immobilized on Hippospongia communis spongin scaffolds. Sci Total Environ. 2018;615:784-95. https://doi.org/10.1016/j. scitotenv.2017.09.213.

80. Chen X, Zhou Q, Liu F, Peng Q, Teng P. Removal of nine pesticide residues from water and soil by biosorption coupled with degradation on biosorbent immobilized laccase. Chemosphere. 2019;233: 49-56. https://doi.org/10.1016/j.chemosphere.2019.05.144.

81. Barrios-Estrada C, de Jesus R-AM, Parra AL, Belleville MP, Sanchez-Marcano J, Iqbal HMN, et al. Potentialities of active membranes with immobilized laccase for bisphenol A degradation. Inter J Biol Macromol. 2018;108:837-44. https://doi.org/10.1016/j. ijbiomac.2017.10.177.

82. Bilal M, Jing Z, Zhao Y, Iqbal HMN. Immobilization of fungal laccase on glutaraldehyde cross-linked chitosan beads and its biocatalytic potential to degrade bisphenol A. Biocatal Agric Biotechnol. 2019;19:101174. https://doi.org/10.1016/j.bcab.2019. 101174.

83. Zhang R, Wang L, Han J, Wu J, Li C, Ni L, et al. Improving laccase activity and stability by HKUST-1 with cofactor via one-pot encapsulation and its application for degradation of bisphenol A. J Hazard Mat. 2020;383:121130. https://doi.org/10.1016/j.jhazmat.2019. 121130.

84. Sadeghzadeh S, Nejad ZG, Ghasemi S, Khafaji M, Borghei SM. Removal of bisphenol A in aqueous solution using magnetic crosslinked laccase aggregates from Trametes hirsute. Bioresour Technol. 2020;306:123169. https://doi.org/10.1016/j.biortech. 2020.123169

85. Chen X, He B, Feng M, Zhao D, Sun J. Immobilized laccase on magnetic nanoparticles for enhanced lignin model compounds degradation. J Chem Eng. 2020;28:2152-9. https://doi.org/10.1016/j. cjche.2020.02.028.

Publisher's Note Springer Nature remains neutral with regard to jurisdictional claims in published maps and institutional affiliations. 